\title{
PEPTIDOLYTIC MICROBIAL COMMUNITY OF METHANOGENIC REACTORS FROM TWO MODIFIED UASBS OF BREWERY INDUSTRIES
}

\author{
C. Díaz ${ }^{1}$; S. Baena ${ }^{1 *}$, B.K.C. Patel ${ }^{2}$, M.L. Fardeau ${ }^{3}$
}

${ }^{1}$ Unidad de Saneamiento y Biotecnología Ambiental (USBA), Departamento de Biología, Pontificia Universidad Javeriana, P.O.B. 56710, Bogotá, Colombia; ${ }^{2}$ Microbial Research Discovery Unit, School of Biomolecular and Biomedical Sciences, Faculty of Science, Griffith University, Brisbane, Queensland 4111, Australia; ${ }^{3}$ IRD, IFR-BAIM, Universités de Provence et de la Méditerranée, ESIL, case 925, 163 Avenue of Luminy, 13288. Marseille Cedex 09. France.

\begin{abstract}
We studied the peptide-degrading anaerobic communities of methanogenic reactors from two mesophilic full-scale modified upflow anaerobic sludge blanket (UASB) reactors treating brewery wastewater in Colombia. Most probable number (MPN) counts varied between $7.1 \times 10^{8}$ and $6.6 \times 10^{9}$ bacteria/g volatile suspended solids VSS (Methanogenic Reactor 1) and 7.2 × $10^{6}$ and 6.4 x $10^{7}$ bacteria/g (VSS) (Methanogenic Reactor 2). Metabolites detected in the highest positive MPN dilutions in both reactors were mostly acetate, propionate, isovalerate and, in some cases, negligible concentrations of butyrate. Using the highest positive dilutions of MPN counts, 50 dominant strains were isolated from both reactors, and 12 strains were selected for sequencing their 16S rRNA gene based on their phenotypic characteristics. The small-subunit rRNA gene sequences indicated that these strains were affiliated to the families Propionibacteriaceae, Clostridiaceae and Syntrophomonadaceae in the low G + C gram-positive group and Desulfovibrio spp. in the class $\delta$-Proteobacteria. The main metabolites detected in the highest positive dilutions of MPN and the presence of Syntrophomonadaceae indicate the effect of the syntrophic associations on the bioconversion of these substrates in methanogenic reactors. Additionally, the potential utilization of external electron acceptors for the complete degradation of amino acids by Clostridium strains confirms the relevance of these acceptors in the transformation of peptides and amino acids in these systems.
\end{abstract}

Key words: anaerobic peptide-degrading bacteria, MPN, UASB, 16S rRNA gene.

\section{INTRODUCTION}

Recent studies on microbial diversity in anaerobic reactors report the presence of Proteobacteria (Alfa, Beta, Delta and Gamma), Firmicutes, Cytophaga-Flexibacter-Bacteroides,
Spirochaetes, Chloroflexi, Planctomyces, and Synergistes (17, $34,9,44,35,7,11,3,15,38)$. The actual diversity and its role in anaerobic reactors remain unclear but the dynamics of microbial composition inside the reactors is related to wastewater characteristics and operational conditions $(24,26)$.

\footnotetext{
*Corresponding Author. Mailing address: Unidad de Saneamiento y Biotecnología Ambiental (USBA). Departamento de Biología. Pontificia Universidad Javeriana, P.O.B. 56710, Bogotá, Colombia.; Tel: +571 3208320 ext. 4170 Fax: +571 3208320 ext. 4056.; E-mail: baena@javeriana.edu.co
} 
The relative abundance and the role of peptide-degrading communities in methanogenic reactors have been largely ignored. Although proteins and peptides are an important component of the wastes produced by the food industries, the anaerobic organisms that degrade these wastes in UASB reactors are still not well characterized $(29,39)$. In anaerobic reactors, proteins are hydrolyzed down to peptides and amino acids, which are fermented to volatile fatty acids and finally converted to methane and carbon dioxide. All these processes take place due to the interactions between microbial populations. Knowledge of microbial community associated to a specific role is relevant to optimize the anaerobic digestion process and increase the stability of the process. The isolation of peptide and aminoacidolytic species has shed light on their complex relations and interactions and has brought into focus the importance of their study in order to enhance the control strategies of the anaerobic reactors. The objective of this study was, therefore, to quantify the most probable number (MPN) of peptide-degrading microorganisms on methanogenic reactors treating brewery wastewater, and to identify, from the highest positive MPN dilutions, the dominant communities of peptide and amino acid degrading microorganisms and their main physiological characteristics.

\section{MATERIALS AND METHODS}

\section{Collection of samples and source of the microbial inocula}

Flocculent mesophilic sludge samples were collected from the methanogenic reactors of two full-scale anaerobic brewery wastewater reactors operating continuously in two phases (acidogenic and methanogenic) during 4 years. Reactor 1 (M1) and reactor $2(\mathrm{M} 2)$ of 500 and $325 \mathrm{~m}^{3}$ capacity respectively, were maintained at an Hydraulic Retention Time (HRT) of 25 h. The Chemical Organic Demand (COD) values were approximately 2,700 mg. $\mathrm{l}^{-1}$. Major constituents of the wastewater were carbohydrates (36 to $42 \%$ of the total COD) and proteins (10 to $21 \%$ of the total COD). The $\mathrm{pH}$ was 7.2 and temperature varied between 28 and $30^{\circ} \mathrm{C}$. Sludge samples were collected from methanogenic reactors in 3 to 4 sampling events within a 200-day period of continuous operation, in order to detect changes over time in numbers of peptide-degrading microorganisms. Samples from reactor 1 were labelled $M 1_{A}$ and $\mathrm{M} 1_{\mathrm{B}}$ for the first experimental unit, and $\mathrm{M} 2_{\mathrm{A}}$ and $\mathrm{M} 2_{\mathrm{B}}$ for the second experimental unit. Samples from reactor 2 were labelled $\mathrm{M}_{\mathrm{A}}$ and $\mathrm{M}_{\mathrm{B}}$. Microbial analyses were carried out with these sub-samples.

\section{Preparation of the sludge samples and microbial counts using the Most Probable Number technique (MPN)}

Ten ml of sludge of each sub-sample were homogenized in anaerobic conditions using a tissue grinder. Serial dilutions from $10^{-1}$ to $10^{-10}$ were prepared from each sub-sample and all the procedures were carried out according to 12 (2007).

The MPN technique was used with three tubes per dilution, and peptide-degrading microorganisms were quantified according to 22 (1969) anaerobic techniques modified by 27(1974). Each sub-sample was cultured in a basal mineral medium (6) and different series were set: series $A_{1}$ : supplemented with $0.2 \%$ casaminoacids; series $\mathrm{A}_{2}: 0.2 \%$ casaminoacids plus $20 \mathrm{mM}$ thiosulfate; series $\mathrm{B}_{1}: 0.2 \%$ pepticase; series $\mathrm{B}_{2}: 0.2 \%$ pepticase plus $20 \mathrm{mM}$ thiosulfate; series $\mathrm{C}_{1}$ : control without substrate and thiosulfate; and $\mathrm{C}_{2}$ : control with thiosulfate alone. Thiosulfate was evaluated as a final electron acceptor that favors the growth of peptidedegrading microorganisms able to use thiosulfate instead of sulfate as an electron acceptor, and/or to quantify directly Sulfate-Reducing Bacteria (SRB) that degrade peptides and amino acids. After an incubation period of 4 weeks at $37{ }^{\circ} \mathrm{C}$, the results of MPN were reported as MPN/g VSS. The criteria to determine positive growth in the tubes were: an increase in optical density $(580 \mathrm{~nm})$, production of sulfide or methane compared to the control series, and microscopic observation.

\section{Analytical Methods}

The parameters $\mathrm{pH}, \mathrm{COD}$, and volatile suspended solids (VSS) were analyzed according to Standard Methods (2). In the series without thiosulfate, methane formation was evaluated using a Shimadzu gas chromatograph (Model GC-14B) 
equipped with an HP-1 column (30 m x $0.53 \mathrm{~mm} \times 0.88 \mu \mathrm{m})$ and a flame ionization detector at $200{ }^{\circ} \mathrm{C}$. Column temperature was $50{ }^{\circ} \mathrm{C}$ and the injection port temperature was $120{ }^{\circ} \mathrm{C}$. Nitrogen $\left(\mathrm{N}_{2}\right)$ was used as the carrier gas. Production of sulfide in the presence of thiosulfate was measured spectrophotometrically (8). Microbial growth and formation of metabolites were analyzed after four weeks of incubation. The end-products (volatile fatty acids) were measured by a Shimadzu High Pressure Liquid Chromatographer equipped with a $\mathrm{C} 18$ reverse-phase ultra aqueous column $(150 \mathrm{~mm} \mathrm{x}$ 4.6mm ID), with Diode Array Detector (SPD-M20A) at 210 $\mathrm{nm}$.

\section{Isolation of dominant peptidolytic bacteria}

From the highest positive MPN dilutions of the two treatment plants, isolation was performed in solid medium with $2 \%$ noble agar (Sigma®) following the roll tube technique (6). Five different culture series were obtained with basic medium supplemented with casaminoacids, pepticase and gelatin at a concentration of $0.8 \%(\mathrm{w} / \mathrm{v})$, and alanine, valine, isoleucine and serine at a concentration of $10 \mathrm{mM}$. These five series were incubated at $37^{\circ} \mathrm{C}$ during 15 days. Isolated strains were purified through the repeated use of the roll tube technique until axenic cultures were obtained. Cell morphology was determined using a phase-contrast microscope. Studies on substrate utilization were carried out in basal medium containing $0.02 \%$ (w/v) yeast extract. Alanine, glutamate, arginine, valine, serine, threonine, histidine, and isoleucine were tested at a final concentration of $10 \mathrm{mM}$; yeast extract, peptone, pepticase and casaminoacids were tested at a final concentration of $0.5 \%(\mathrm{w} / \mathrm{v})$; and lactate, piruvate, acetate, propionate, butirate, maltose, D-xilose, Dmanitol, D-arabinose, D-glucose, and ethanol at a final concentration of $20 \mathrm{mM}$. The end-products were measured by High Pressure Liquid Chromatography as described before. Spores were evaluated under the microscope from cultures incubated at $80{ }^{\circ} \mathrm{C}$ for up to $20 \mathrm{~min}$, and at $90^{\circ} \mathrm{C}$ for up to 10 min followed by subculturing into growth medium. To examine the utilization of potential electron acceptors, $20 \mathrm{mM}$ thiosulfate, $20 \mathrm{mM}$ sulfate, $2 \mathrm{mM}$ sulfite, and $1.0 \%(\mathrm{w} / \mathrm{v})$ elemental sulfur were used in basal medium with a carbon source selected depending on the results of substrate utilization studies. Sulfide was determined spectrophotometrically, as indicated above.

\section{Mixed culture experiments}

Methanotrophic microorganisms were used in co-culture with selected strains to evaluate the degradation of peptides and amino acids. Methanothermobacter thermoautotrophicus $\mathrm{Z}$ 245 and Methanospirillum hungatei (gently donated by Dr. Caroline Plugge, Laboratory of Microbiology, Wageningen University, Netherlands) and Methanobacterium formicicum (DSM 1535) were grown under a $\mathrm{H}_{2}: \mathrm{CO}_{2}$ (80:20) atmosphere in basal medium, containing $0.1 \%(\mathrm{w} / \mathrm{v})$ yeast extract, $M$. thermoautotrophicus Z 245 incubated at $50^{\circ} \mathrm{C}$ and M. hungatei and M. formicicum at $37{ }^{\circ} \mathrm{C}$.. The isolated strains Ile-2 and Gela were grown in basal medium containing $2 \%(w / v)$ pepticase and $0.02 \%$ yeast extract and incubated at $37^{\circ} \mathrm{C}$ and $50^{\circ} \mathrm{C}$, respectively. The inoculum from methanogenic archaea and isolated strains (10\%) were injected into tubes containing 5 $\mathrm{ml}$ basal medium, $0.02 \%(\mathrm{w} / \mathrm{v})$ yeast extract and selected amino acids (arginine, histidine, alanine, threonine, isoleucine, glutamate and valine) at a final concentration of $10 \mathrm{mM}$ and, casaminoacids at $1.0 \%(\mathrm{w} / \mathrm{v})$. The co-cultures $(M$. thermoautotrophicus Z 245 and strain Gela; M. formicicum or $M$. hungatei and strain Ile-2) were incubated for 2 weeks after the end-products were determined. The controls used were basal medium containing $0.02 \%$ yeast extract but lacking amino acids. Amino acid degradation via the Stickland reaction was tested in a basal medium containing $10 \mathrm{mM}$ alanine as electron donor and $20 \mathrm{mM}$ glycine, serine, proline or arginine as electron acceptor.

\section{Analysis of the 16s rRNA gene sequences of the isolated strains}

Methods for purifying DNA, PCR-amplification, sequencing of the $16 \mathrm{~S}$ rRNA gene and phylogeny were as described previously $(30,43,36)$. Partial sequences generated were assembled using BioEdit v5.0.1 (19) and the consensus 
sequence of 1,430 nucleotides was corrected manually for errors. The most closely related sequences in the GenBank (version 152) and the Ribosomal Database Project II (RDP) (release 10) identified using BLAST (1) were extracted, aligned and manually adjusted according to the 16S rRNA secondary structure obtained from RDP using BioEdit. Nucleotide ambiguities were omitted and evolutionary distances calculated by using the Jukes and Cantor option (23) in TreeCon (41). Phylogenetic trees were constructed from evolutionary distances using the Neighbour-Joining method (32). Tree topology was re-examined by bootstrap method (1000) of re-sampling (14). The 16S rRNA sequences from this study have been submitted to NCBI GenBank Database under accession numbers EU937733 to EU937739; EU980605 to EU980608, and AY 642589.

Statistical analysis was performed by a completely random design with a $2 \times 2$ factorial arrangement corresponding to these variables: substrates, electron acceptors, and interactions between them. Four replicates were made. Variance was analyzed with the program Statistix 7.0 for Windows. The dependent variable (number of microorganisms) was transformed using the $\log _{10}$ function in order to reduce the variation coefficient and to apply parametric statistics.

\section{RESULTS AND DISCUSSION}

The efficiency on removal of COD in UASB reactors ranged between 81 and $92 \%$ during the study. The $\mathrm{pH}$ values fluctuated between 6.8 and 7.0. The ratio of volatile fatty acids: alkalinity (VFA:Alk) was around 0.84 , indicating high values for VFA. The temperature varied between 28 and $31^{\circ} \mathrm{C}$.

\section{Microbiological Analysis}

Most probable number (MPN) counts varied between $7.1 \mathrm{x}$ $10^{8}$ and $6.6 \times 10^{9}$ bacteria/g VSS (Reactor 1 ) and $7.2 \times 10^{6}$ and $6.4 \times 10^{7}$ bacteria/g VSS (Reactor 2) (Tables 1 and 2). Variance analysis (level of confidence of 95\%) did not show a significant influence of substrates or thiosulfate over the peptide-degrading population density in both reactors $(p>$ 0.05). Significant changes in the count values through time were not observed. The two-phase anaerobic digesters allow enrichment for different bacteria in each acidogenic and methanogenic reactor linked to the available substrates and operational conditions (24). In our study, high microbial counts of peptide-degrading microorganisms obtained indicate that degradation of peptides is an important metabolic activity in the methanogenic reactors.

Table 1. MPN of peptidolytic populations of flocculent sludge (Reactor 1).

\begin{tabular}{lcccc}
\hline \multicolumn{1}{c}{ Series } & $\begin{array}{c}\text { Sampling 1 } \\
\text { Cell/g VSS }\end{array}$ & $\begin{array}{c}\text { Sampling 2 } \\
\text { Cell/g VSS }^{*}\end{array}$ & $\begin{array}{c}\text { Sampling 3 } \\
\text { Cell/g VSS }^{*}\end{array}$ & $\begin{array}{c}\text { Sampling 4 } \\
\text { Cell/g VSS }^{*}\end{array}$ \\
\hline A1: MB + Casa & $5.1 \times 10^{9}$ & $2.5 \times 10^{9}$ & $1.8 \times 10^{9}$ & $3.2 \times 10^{9}$ \\
A2: MB + Casa+ Thio & $8.2 \times 10^{8}$ & $2.5 \times 10^{9}$ & $4.8 \times 10^{9}$ & $1.7 \times 10^{9}$ \\
B1: MB + Pept & $6.0 \times 10^{9}$ & $4.9 \times 10^{9}$ & $6.6 \times 10^{9}$ & $6.6 \times 10^{9}$ \\
B2: MB + Pep +Thio & $7.1 \times 10^{8}$ & $2.1 \times 10^{9}$ & $1.8 \times 10^{9}$ & $1.8 \times 10^{9}$ \\
\hline
\end{tabular}

* Arithmetical average of four replicates

MB: Basal medium; Casa: $0.2 \%$ w/v casaminoacids; Pept: $0.2 \%$ w/v pepticase; Thio: $20 \mathrm{mM}$ Thiosulfate

Table 2. MPN of peptide-degrading populations of flocculent sludge (Reactor 2).

\begin{tabular}{lccc}
\hline \multicolumn{1}{c}{ Series } & $\begin{array}{c}\text { Sampling 1 } \\
\text { Cells/g VSS* }\end{array}$ & $\begin{array}{c}\text { Sampling 2 } \\
\text { Cells/g VSS* }\end{array}$ & $\begin{array}{c}\text { Sampling 3 } \\
\text { Cells/g VSS* }\end{array}$ \\
\hline A1: MB + Casa & $1.1 \times 10^{7}$ & $3.5 \times 10^{7}$ & $6.4 \times 10^{7}$ \\
A2: MB + Casa+ Thio & $1.1 \times 10^{7}$ & $6.4 \times 10^{7}$ & $3.7 \times 10^{7}$ \\
B1: MB + Pept & $2.6 \times 10^{7}$ & $2.2 \times 10^{7}$ & $2.7 \times 10^{7}$ \\
B2: MB + Pep +Thio & $2.6 \times 10^{7}$ & $7.2 \times 10^{6}$ & $3.2 \times 10^{7}$ \\
\hline
\end{tabular}

* Arithmetical average of two replicates

MB: Basal medium; Casa: $0.2 \%$ w/v casaminoacids; Pept: $0.2 \% \mathrm{w} / \mathrm{v}$ pepticase; Thio: $20 \mathrm{mM}$ Thiosulfate 
The main metabolites detected in the highest positive dilutions of the series of cultures were acetate, propionate, and isovalerate, and in some cases, negligible concentrations of butyrate. This volatile fatty acid (VFA) production could be explained by a population selection according to the type of substrate (10). Single amino acids can be degraded either through fermentation or oxidative deamination linked to proton reduction and, the reducing equivalents produced can be removed by a biological or a chemical electron scavenger (37, 33). This is possible via interspecies hydrogen transfer in the presence of hydrogenotrophic methanogens or SRB, but also when thiosulfate acts as the final electron acceptor (13). Peptide and amino acid-degrading microorganisms produce acetate, propionate, and the corresponding branched-chain fatty acids syntrophically, depending on the degraded amino acids (5). In our study, the formation of VFA can be related to the degradation of amino acids in the presence of thiosulfate as electron acceptor or in syntrophic association with hydrogenotrophic methanogenic bacteria coming from the initial inocula. In the thiosulfate series, sulfide values between 5 and $8 \mathrm{mM}$ were detected, indicating its reduction during the oxidation of carbon sources. Additionally, in absence of thiosulfate, a low concentration of methane was detected in the highest positive dilutions.

On the other hand, it has been established that the fast growing peptidolytic organisms that do not depend on syntrophic associations produce butyrate as the main metabolite (28). The negligible concentrations of butyrate obtained in our counts and the fact that none of the 50 isolated strains produced butyrate as final metabolite, help to confirm that these dominant peptide-degrading bacteria, that utilize peptide and/or amino acids as the sole carbon and energy source can depend on syntrophic associations or final electron acceptors.

\section{Isolation of dominant peptidolytic bacteria}

During the last sampling event, 50 strains with different morphological characteristics were isolated from both reactors:
Gram-positive and Gram-negative bacilli, motile and nonmotile, spore and non-spore forming, single or paired, in chains or in groups. The isolated strains were grouped by their phenotypic characteristics, such as Gram stain, strict anaerobiosis, spore formation, motility and degradation of peptides and / or amino acids. Subsequently, some of these microorganisms were selected for sequenciation and analysis of the $16 \mathrm{~S}$ rRNA gene. Finally, 12 microorganisms named M1, MD-4, Ser-1, Ser-2, Ala-1, Val-6, Gela-Thio, Gela, MG-2, B2-2M, MP-6, e Ile-2 were evaluated.

Phylogenetic analysis of the 16S rRNA gene sequence grouped these strains (Figure 1) into three phyla: Proteobacteria, Actinobacteria and Firmicutes. Four strains isolated from the series without thiosulfate and identified as Desulfovibrio vulgaris (strains $\mathrm{M}-1$ and MD-4) and Desulfovibrio desulfuricans (strains Ser-1 and Ser-2) belong to the class $\delta$-Proteobacteria. These strains fermented serine in absence of an external electron acceptor, producing acetate as the main metabolite. The presence of peptide and amino acid degraders via fermentation of the genus Desulfovibrio in, anaerobic reactors has been widely reported $(4,20,24)$. The presence of SRB in the highest positive dilutions of the microbial counts in this study would indicate their possible role in the fermentation of amino acids in methanogenic reactors where sulfate appears at low concentrations (values of sulfate detected ranged from 4 to $29 \mathrm{mg} .1^{-1}$ in both reactors).

Strains MP-6 and B2-2M, belonging to the phylum Actinobacteria, were grouped in the family Propionibacteriaceae. They are strictly anaerobic saccharolytic organisms, non-motile and mesophilic. Strain MP-6 produces acetate and propionate from glucose, and ferments yeast extract but does not use external electron acceptors. Strain B2-2M produces acetate and traces of ethanol from glucose, it also ferments casaminoacids, peptone, pepticase, arginine and yeast extract, and it is able to reduce the elemental sulfur to hydrogen sulfide. Based on the analysis of the 16S rRNA gene both strains are close to the clone B2, isolated from a microbial enrichment with propionate from an 
anaerobic reactor (31) (98\% similarity) and also related to Propionibacterium lymphophilum with $93 \%$ of similarity.
Luteococcus peritonei is related with $91 \%$ and $94 \%$ similarity to strains MP-6 and B2-2M respectively.

\section{1}

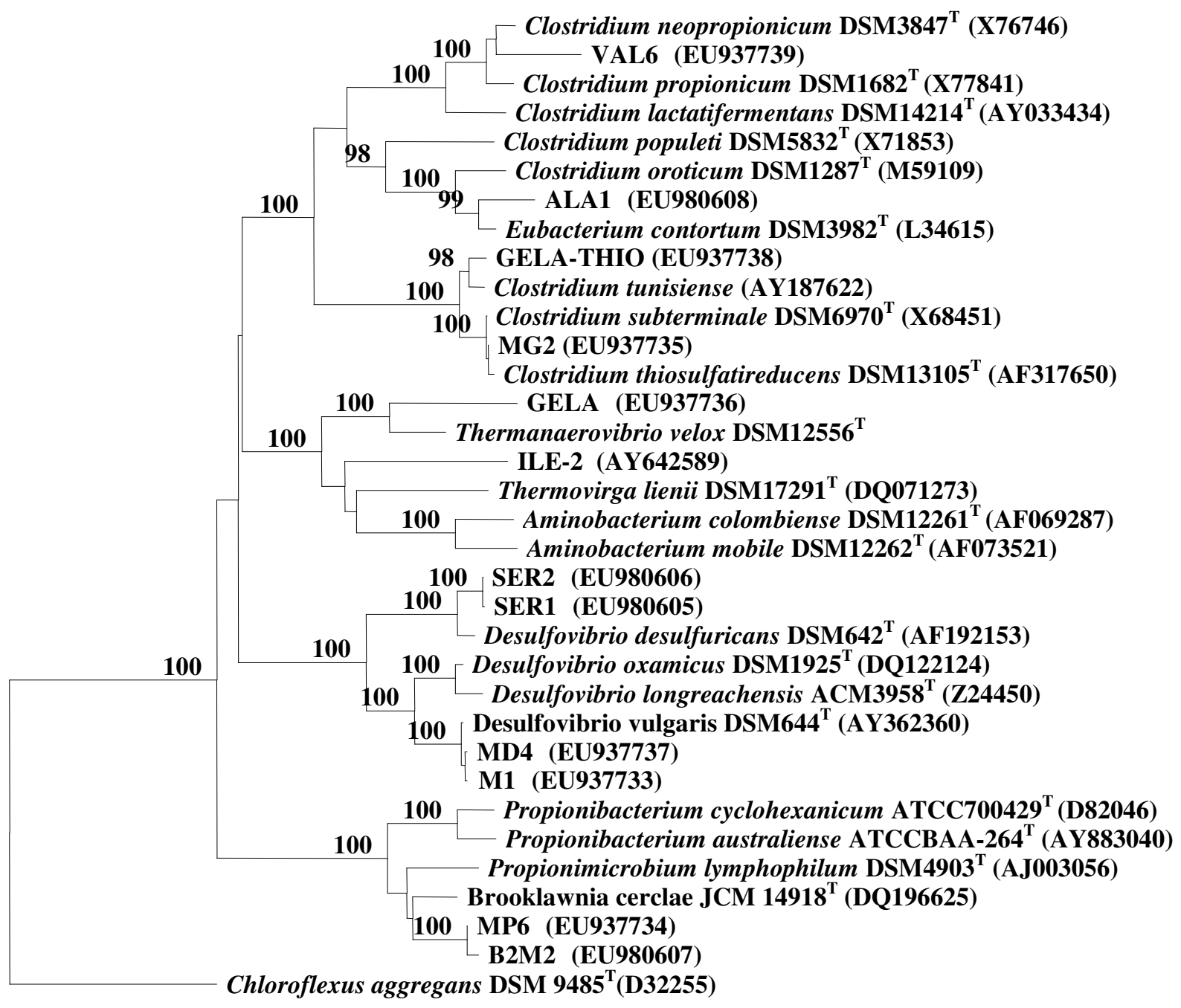

Figure 1. Tree constructed using Neighbour-Joining method (Jukes-Cantor correction) based on 16S rRNA gene sequences showing the position of strains MP6, B2M2, GELA, ILE-2, SER1, SER2, MD4, M1, MG2, GELA-TIO, ALA1, VAL6 and some related taxa. Bootstrap values (expressed as percentages of 1,000 replications) above 95\% are shown at branch points (Bar: 0.1 substitutions per nucleotide position).

Phylum Firmicutes was represented by three different families (Clostridiaceae, Eubacteriaceae, and Syntrophomonadaceae). The majority of strains related to the degradation of proteins and/amino acids are affiliated to this phylum. These organisms could play a central role in the degradation of proteins, peptides and amino acids as reported by 39 (2005) and indicated by our own results. Strain Ala-1 belongs to the family Eubacteriaceae and was identified as 
Eubacterium contortum (99\% of similarity). This strain is strictly anaerobic, mesophilic and saccharolytic, but does not degrade casamino acids, pepticase or peptone and does not use external electron acceptors. Although the family Eubacteriaceae includes species such as Eubacterium acidaminophilum capable of using aminoacids and peptides (45), strain Ala-1 did not degrade peptides or amino acids. This strain probably grew at the expense of the metabolites produced by other organisms in the highest positive dilutions of the counts.

Strains Gela-Thio, MG-2 and Val-6 belong to the family Clostridiaceae and share similarity percentages of 98, 99 and 95\% with C. tunisiense (40), C. thiosulfatireducens (21) and $C$. neopropionicum, respectively. Strains Gela-Thio, Val-6 and MG-2 are strictly anaerobic, mesophilic, asaccharolytic and ferment peptides and amino acids mainly producing acetate and propionate. As electron acceptors, strains Gela-Thio and Val-6 use elemental sulfur and strain MG-2 uses thiosulfate. Based on the similarity of $16 \mathrm{~S}$ rRNA gene sequences, strain GelaThio is identified as $C$. tunisiense, and strain MG-2 as $C$. thiosulfatireducens. The value of similarity between strain Val6 and $C$. neopropionicum and their phenotypic differences do not allow identifying strain Val-6 as C. neopropionicum. Our results demonstrate that isolates in presence of electron acceptors (elemental sulfur or thiosulfate) can degrade amino acids via oxidative deamination. These external electron acceptors are important in the degradation of amino acids since they remove the reducing equivalents formed during their degradation. This mechanism has been reported in anaerobic bacteria such as Thermoanaerobacter spp. and Dethiosulfovibrio spp. (13, 25). Strain MG-2, besides using thiosulfate as final electron acceptor, also uses the Stickland reaction to degrade amino acids. Strain Val-6 could be identified as a new species of the genus Clostridium, according to the analysis of their 16S rRNA sequence and observed phenotypic differences, but further studies are needed in order to confirm this hypothesis.

Strains Gela (Figure 2) and Ile-2 belong to the family Syntrophomonadaceae, which includes a group of anaerobes that commonly grow in syntrophic associations with hydrogen and formate using methanogens. Strain Gela is strictly anaerobic, thermophilic (optimum growth at $50^{\circ} \mathrm{C}$ ), motile, non-spore forming and saccharolytic. This strain fermented amino acids (serine, threonine, histidine, glutamate, valine, isoleucine, leucine, and arginine) and peptides (casamino acids, peptone and yeast extract) and reduced elemental sulfur to hydrogen sulfide as external electron acceptor. It showed a similarity of $96 \%$ with Thermanaerovibrio acidaminovorans and could only completely degrade amino acids as alanine, valine, leucine and glutamate in syntrophic association with hydrogenotrophic organisms (Methanothermobacter thermoautotrophicus strain Z245) (Table 3). These characteristics are shared with Thermanaerovibrio acidaminovorans.

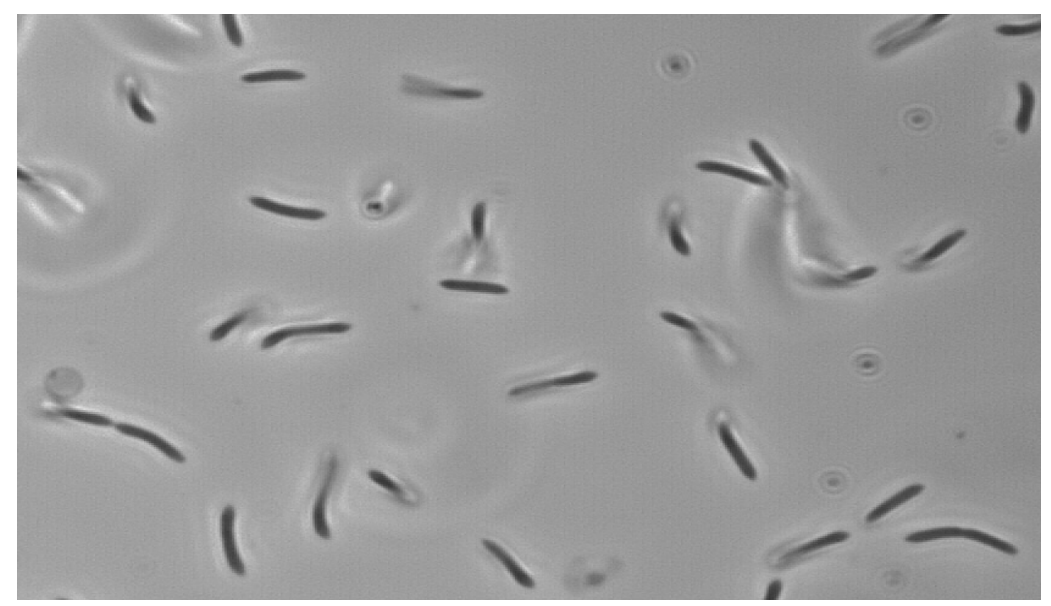

Figure 2. Photomicrograph with phase contrast microscope of cells of strain Gela in exponential growth phase (Bar: $5 \mu \mathrm{m})$. 
Table 3. Conversion of substrates by strain Gela in the presence of the absence of Methanothermobacter thermoautotrophicus $\mathrm{Z} 245^{(\mathrm{a})}$

\begin{tabular}{|c|c|c|c|c|}
\hline \multirow[t]{2}{*}{ Substrate } & \multicolumn{4}{|c|}{ Products analyzed $(\mathrm{mM})$} \\
\hline & acetate & propionate & ${ }^{(b)} \mathrm{H}_{2} / \mathrm{CH}_{4}$ & others \\
\hline Glu & 1.0 & 4.6 & 5.4 & \\
\hline Glu + Z245 & 5.3 & 7.2 & 14.4 & \\
\hline Arg & $>0.5$ & 1.6 & 2.0 & \\
\hline Arg + Z 245 & $>0.5$ & 8.7 & 23.6 & \\
\hline Ile & $>0.5$ & 0.0 & 2.5 & 0.5 2-methyl-butyrate \\
\hline Ile + Z 245 & $>0.5$ & 0.0 & 22.8 & 8.9 2-methyl-butyrate \\
\hline Ala & 1.54 & 0.0 & 2.0 & \\
\hline $\mathrm{Ala}+\mathrm{Z} 245$ & 11.3 & 0.0 & 16.8 & \\
\hline Val & 0.0 & 0.0 & 1.6 & 2.7 iso-butyrate \\
\hline $\mathrm{Val}+\mathrm{Z} 245$ & 0.0 & 0.0 & 12.0 & 7.9 iso-butyrate \\
\hline Leu & 0.0 & 0.0 & 3.4 & 1.4 iso-valerate \\
\hline Leu + Z 245 & 0.0 & 0.0 & 16 & 9.5 iso-valerate \\
\hline Ornithine & 0.64 & 1.4 & 3.2 & \\
\hline Ornithine + Z 245 & $>0.5$ & 8.2 & 22.4 & \\
\hline Casa & 6.8 & & 5.3 & \\
\hline Casa + Z 245 & 12.6 & 15.2 & 31.2 & 2.4 iso-butyrate; 2.85 2-methyl-butyrate \\
\hline His & $>0.5$ & 3.2 & 2.3 & 17.5 formate \\
\hline His + Z 245 & $>0.5$ & 6.5 & 12 & \\
\hline Thr & 16.7 & $>0.5$ & $>0.5$ & \\
\hline Thr + Z 245 & 9.2 & & $>0.2$ & \\
\hline
\end{tabular}

Strain Ile-2 is a Gram-negative, slightly curved, strictly anaerobic, mesophilic (optimum growth at $42^{\circ} \mathrm{C}$ ) bacillus and we could define it as a new genus named Aminiphilus (12). The strain showed a similarity of $85 \%$ with Aminomonas paucivorans (5) and of $95 \%$ with clone BB48 isolated from 16S rDNA genomic libraries of anaerobic reactors $(17,7)$. This strain fermented peptides and amino acids such as serine, alanine, glutamate, isoleucine and valine, mainly producing acetate, propionate and short-chained fatty acids. However, it did not degrade threonine or glycine, substrates commonly used by A. paucivorans.

Syntrophomonadaceae is represented by 16 genera that have been isolated from anaerobic wastewater treatment systems and oil wells. The majority of their members use syntrophic associations with hydrogenotrophic organisms to completely degrade amino acids and/or peptides. The presence of organisms of the division Synergistes (family Syntrophomonadaceae) was evaluated in 93 anaerobic ecosystems (18), concluding that the ecophysiologic role of the majority of these organisms is the degradation of amino acids. 
Interestingly, in a reactor fed with bovine serum albumin, when the growth of methanogenic microorganisms was favored, the dominant populations were related to the genus Aminobacterium (39) that could use syntrophic associations to degrade substrates (6). Our study also concludes that in the absence of methanogenic organisms, the degradation pathway of peptide and amino acids is linked to fast growing organisms of the genus Clostridium. Recently, a new example of an asaccharolytic amino acid degrading bacterium within the phylum 'Synergistetes' named Cloacibacillus evryensis was reported by 16. (2008), from an anaerobic sludge digester, indicating its role in this kind of ecosystems. The organisms of the division Synergistes that are phylogenetically related to the family Syntrophomonadaceae, share the ability to degrade amino acids (18), whether by syntrophic associations or by the presence of an external electron acceptor. It was pointed out that in absence of either of these mechanisms, there is a relationship between phylogeny and function among members of this division, related to the conversion of peptides and amino acids in anaerobic ecosystems (42).

\section{CONCLUSIONS}

These methanogenic reactors exhibit an important anaerobic community of the domain Bacteria. Using conventional techniques, we identified peptide and/or amino acid degrading microorganisms and their activities in anaerobic reactors. The analysis of metabolites produced and the presence of species of microorganisms of the family Syntrophomonadaceae, strains Ile-2 and Gela, indicates the possible effect of the syntrophic associations on the bioconversion of these substrates in methanogenic reactors. Furthermore, the utilization of external electron acceptors for the complete degradation of amino acids by strains Val-6, MG2 and Gela-Thio confirms the relevance of these acceptors in the transformation of peptides and amino acids in these anaerobic systems.

\section{ACKNOWLEDGMENTS}

This study was supported by IFS (International Foundation for Science) and COLCIENCIAS (Instituto Colombiano para el Desarrollo de la Ciencia y la Tecnología). We thank Eng. Juan Carlos Hoyos of Cervecería Bavaria for providing the physicochemical data of the two treatment systems, and Dr. Caroline Plugge of the Laboratory of Microbiology, Wageningen University, for allowing us to evaluate the metabolism of strain GELA in her lab.

\section{REFERENCES}

1. Altschul, S.F.; Madden, T.L.; Schäffer, A.A.; Zhang, J.; Zhang, Z.; Miller, W.; Lipman, D.J. (1997). Gapped BLAST and PSI-BLAST: a new generation of protein database search programs. Nucleic Acids Res $25,3389-3402$

2. APHA. (1995). Standard methods for the examination of water and wastewater. Ninteenth ed. American Public Health Association, Washington, DC.

3. Ariesyady, H.D.; Ito, T.; Okabe, S. (2007). Functional bacterial and archaeal community structures of major trophic groups in a full-scale anaerobic sludge blanket. Wat Res 41, 1554-1568.

4. Baena, S.; Fardeau, M.L., Labat, M.; Ollivier, B.; Garcia, J.L.; Patel, B.K.C. (1998). Desulfovibrio aminophilus sp. nov., a novel amino acid degrading and sulfate-reducing bacterium from an anaerobic dairy wastewater lagoon. Syst. Appl. Microbiol. 21, 498-504.

5. Baena S.; Fardeau, M.L.; Labat, M.; Ollivier, B.; Thomas, P.; Patel, B.K.C. (1999). Aminomonas paucivorans gen. nov., sp. nov., a mesophilic, anaerobic, amino-acid utilising bacterium. Int. J. Syst. Bacteriol. 49, 975-982.

6. Baena S.; Fardeau, M.L.; Labat, M.; Ollivier, B.; Patel, B.K.C. (2000). Aminobacterium mobile sp. nov., a new anaerobic amino acid degrading bacterium. Int. J. Syst. Evol. Microbiol. 50, 259-264.

7. Chouari, R.; Le Paslier, D.; Dauga, C.; Daegelen, P.; Weissenbach, J.; Sghir, A. (2005). Novel major bacterial candidate division within a municipal anaerobic sludge digester. Appl. Environ. Microbiol. 4, 21452153.

8. Cord-Ruwisch, R. (1985). A quick method of determination of dissolved and precipitated sulfides in cultures of sulfate-reducing bacteria. $J$. Microbiol. Methods. 4:33-36

9. Dèlbes, C.; Moletta, R.; Godon, J.J. (2000). Monitoring of activity dynamics of an anaerobic digester bacterial community using 16S rRNA polymerasa chain reaction-single-strand conformation polymorphism analysis. Environ. Microbiol. 5, 506-515.

10. Demirel, B.; Yenigün, O. (2006). Changes in microbial ecology in an anaerobic reactor. Bioresource Technology. 97, 1201-1208.

11. Díaz, E.; Stams, A.J.; Amils, AR.; Sanz, J.L. (2006). Phenotypic properties and microbial diversity of methanogenic granules from a full- 
scale upflow anaerobic sludge bed reactor treating brewery wastewater. Appl. Environ. Microbiol. 7, 4942-4949.

12. Díaz, C.; Patel, B.K.C.; Fardeau, M.L.; Baena, S. (2007). Aminiphilus circumscriptus gen. nov. sp. nov., an anaerobic amino acid degrading bacterium from an upflow anaerobic sludge reactor. Int. J. Syst. Evol. Microbiol. 57, 1914-1918

13. Faudon, C.; Fardeau, M.L.; Heim, J.; Patel, B.K.C.; Magot, M.; Ollivier, B. (1995). Peptide and amino acid oxidation in the presence of thiosulfate by members of the genus Thermoanaerobacter. Current Microbiol. 30:16.

14. Felsenstein, J. (1985). Confidence limits on phylogenies: An approach using the bootstrap. Evolution, 39, 783-791

15. Fernández, N.; Díaz, E.E.; Amils, R.; Sanz, J.L. (2008). Analysis of microbial community during biofilm development in an anaerobic waste water treatment reactor. Microb. Ecol. 56, 121-132.

16. Ganesan, A.; Chaussonnerie, S.; Tarrade, A.; Dauga, D.; Bouchez, T.; Pelletier, E.; Le Paslier D.; Sghir, A. (2008). Cloacibacillus evryensis gen. nov., sp. nov., a novel asaccharolytic, mesophilic, amino-aciddegrading bacterium within the phylum 'Synergistetes', isolated from an anaerobic sludge digester. Int J Syst Evol Microbiol. 58, 2003-2012

17. Godon, J.J.; Zumstein, E.; Dabert, P.; Habouzit, F.; Moletta, R. (1997). Molecular microbial diversity of an anaerobic digestor as determined by small-subunit rDNA sequence analysis. Appl. Environ. Microbiol. 7, 2802-2813.

18. Godon, J.J.; Molinière, J.; Moletta, R.; Gaillac, M.; Bru, V.; Delgènes, J.P. (2005). Rarity associated with specific ecological niches in the bacterial world: the "Synergistes" example. Environ. Microbiol. 2, 213224.

19. Hall, T.A. (1999). BioEdit: a user-friendly biological sequence alignment editor and analysis program for Windows 95/98/NT. Nucleic Acids Symp Ser. 41, 95-98.

20. Hernandez-Eugenio, G.; Fardeau, M.L.; Patel, B.K.C.; Macarie, H.; Garcia, J.L.; Ollivier, B. (2000). Desulfovibrio mexicanus sp. nov., a sulfate-reducing bacterium isolated from an upflow anaerobic sludge blanket (UASB) reactor treating cheese wastewater. Anaerobe. 6:305312.

21. Hernandez-Eugenio, G.; Fardeau, M.L.; Cayol, J.L.; Patel, B.K.C.; Thomas, P.; Macarie, H.; García, J.L.; Ollivier, B. (2002). Clostridium thiosulfureducens sp. nov., a proteolytic, thiosulfate- and sulfur-reducing bacterium isolated from an upflow anaerobic sludge blanket (UASB) reactor. Int. J. Syst. Evol. Microbiol. 52, 1461-1468.

22. Hungate, R.E. (1969). A roll tube method for the cultivation of strict anaerobes. In: Methods in Microbiology. J.R. Norris, D.W. Ribbons (eds)., Vol 3 B Academic Press, New York.

23. Jukes, T.H.; Cantor, C.R. (1969). Evolution of protein molecules. In Mammalian Protein Metabolism, pp. 21-123. H. H. Munro (ed). New York. Academic Press.

24. Liu, W.T.; Chan, O.C.; Fang, H.H.P. (2002). Characterization of microbial community in granular sludge treating brewery wastewater.
Wat Res. 36: 1767-1775.

25. Magot, M.; Ravot, G.; Campaignolle, X.; Ollivier, B.; Patel, B.K.C.; Fardeau, M.L.; Thomas, P.; Crolet, J.L.; García, J.L. (1997). Dethiosulfovibrio peptidovorans gen. nov., sp. nov., a new anaerobic, slightly halophilic, thiosulfate reducing bacterium from corroding offshore in wells. Int. J. Sys. Bacteriol. 3, 818-824.

26. McHugh, S.; Carton, M.; Mahony, T.; O’Flaherty, V. (2003). Methanogenic population structure ina variety of anaerobic reactors. FEMS Microbiol. Lett. 219: 297-304.

27. Miller, T.L.; Wolin, M.J. (1974). A serum bottle modification of Hungate technique for cultiving obligate anaerobes. Appl. Microbiol. 27:985-987.

28. Plugge, C.; Balk, M.; Zoetendal, E.; Stams, A.J.M. (2002). Gelria glutamica gen. nov., sp. nov., a thermophilic, obligate syntrophic, glutamate-degrading anaerobe. Int. J. Syst. Evol. Microbiol. 52, 401-407.

29. Ramsay, I.R.; Pullammanappallil, P.C. (2001). Protein degradation during anaerobic wastewater treatment: derivation of stoichiometry. Biodegradation. 12, 247-257.

30. Redburn, A.C.; Patel, B.K.C. (1993). Phylogenetic analysis of Desulfotomaculum thermobenzoicum using polymerase chain reactionamplified 16S rRNA-specific DNA. FEMS Microbiol Lett.113, 81-86

31. Roest, K.; Heilig, H.; Smidt, H.; de Vos, W.M.; Stams, A.J.M.; Akkermans, A.D.L. (2005). Community analysis of a full-scale anaerobic bioreactor treating paper mill wastewater. Syst. Appl. Microbiol. 28, 175185.

32. Saitou, N.; Nei, M. (1987). The neighbor-joining method: a new method for reconstructing phylogenetic trees. Molecular Biological Evolution. 4, 406-425.

33. Schink, B. (1997). Energetic of syntrophic cooperation in methanogenic degradation. Microbiol Mol Bio Rev. 61: 262-280.

34. Sekiguchi, Y.; Kamagata, Y.; Syutsubo, K.; Ohashi, A.; Harada, H.; Nakamura, K. (1998). Phylogenetic diversity of mesophilic and thermophilic granular sludges determined by 16S rRNA gene analysis. Microbiology. 144, 2655-2665.

35. Sekiguchi, Y. (2006). Yet to be cultured microorganisms relevant to methane fermentation process. Microbes Environ. 21 1-15.

36. Spanevello, M.D.; Yamamoto, H.; Patel, B.K.C. (2002). Thermaerobacter subterraneus sp. nov., a novel aerobic bacterium from the Great Artesian Basin of Australia, and emendation of the genus Thermaerobacter. Int. J. Syst. Evol. Microbiol.52, 795-800.

37. Stams, A.J.M. (1994). Metabolic interactions between anaerobic bacteria in methanogenic environments. Anton van Leeuw. 66, 271-294.

38. Sun, Y.; Zuo, J.; Chen, L. (2008). Eubacteria and Archaea community of simultaneous methanogenic and denitrification granular sludge. J. Environmental Sciences. 20, 626-631.

39. Tang, Y.; Shigematsu, T.; Morimura, S.; Kida, K. (2005). Microbial community analysis of mesophilic anaerobic protein degradation process using bovine serum albumin (BSA)-fed continuous cultivation. J. Biosc. Bioeng. 2, 150-164.

40. Thabet, O.B.D.; Fardeau, M.L.; Joulian, C.; Thomas, P.; Hamdi, M.; 
Garcia, J.L.; Ollivier, B. (2004). Clostridium tunisiense sp. nov., a new proteolytic, sulphur-reducing bacterium isolated from an olive mil wastewater contaminated by phosphogypse. Anaerobe. 10, 185-190.

41. Van de Peer, Y.; Jansen, J.; de Rijk, P.; de Wachter, P. (1997). Database on the structure of small ribosomal subunit RNA. Nucleic Acids Res 25, 111-116.

42. Vartoukian, S.R.; Palmer, R.M.; Wade, W.G. (2007). The division "Synergistes". Anaerobe. 13, 99-106.

43. Woo, T.H.S.; Patel, B.K.C.; Smythe, L.D.; Symonds, M.L.; Norris, M.A.; Dohnt, M.F. (1997). Comparison of two PCR methods for rapid identification of Leptospira genospecies interrogans. FEMS Microbiol Lett. 155, 169-177.

44. Wu, J.H.; Liu, W.T.; Tseng, I.C.; Cheng, S.S. (2001). Characterization of microbial consortia in a terephtalate-degrading anaerobic granular sludge system. Microbiology. 147, 373-382.

45. Zindel, U.; Freudenberg, W.; Rieth, M.; Andresen, J.R.; Schnell, J.R.; Widdel, F. (1988). Eubacterium acidaminophilum sp. nov., a versatile amino acid-degrading anaerobe producing or utilizing $\mathrm{H}_{2}$ or formate. Arch. Microbiol. 150, 254-266. 